\title{
Neurofibromin Is Enriched in the Endoplasmic Reticulum of CNS Neurons
}

\author{
Michael Nordlund, Xiao Gu, Michael T. Shipley, and Nancy Ratner \\ Department of Anatomy and Cell Biology, University of Cincinnati, College of Medicine, Cincinnati, Ohio 45267-0521
}

\begin{abstract}
NF1 patients display CNS abnormalities including learning disabilities, clumsiness, astrocytomas, and abnormalities on magnetic resonance imaging exams. To determine whether the cellular and neuroanatomical distribution of neurofibromin reveals possible function for neurofibromin in the brain, we stained rat brain tissue sections with anti-neurofibromin antibodies. Neurofibromin is highly enriched in large projection neurons, such as cortical and hippocampal pyramidal cells and cerebellar Purkinje cells. Neurofibromin is present in cell bodies and in axons, but is highly enriched in dendrites. Immunoelectron microscopic analysis demonstrates that NF1 is associated with smooth vesiculotubular elements and cisternal stacks and with multivesicular bodies in the cell body and dendrites, but not with the plasma membrane, nucleus, nuclear envelope, Golgi apparatus, mitochondria, or rough endoplasmic reticulum. The preferential localization of neurofibromin to the smooth endoplasmic reticulum, together with evidence that neurofibromin modulates ras GTPase activity, suggests that some, if not all, of the CNS manifestations of NF1 might result from the altered expression of neurofibromin in neurons, perhaps through disruption of $\mathrm{Ca}^{2+}$ signaling, translocation of organelles, or endocytic pathways.
\end{abstract}

[Key words: ras, Purkinje cell, pyramidal cell, learning disability, motor disorders, cisternal stacks, smooth endoplasmic reticulum, calcium, microtubules, organelle movement]

Von Recklinghausen's neurofibromatosis (NF1) is an autosomal dominantly inherited disorder that affects 1 in 3500 humans (Riccardi, 1981; Eldridge et al., 1989). Although the most frequently reported abnormalities involve derivatives of the neural crest, a variety of stigmata associated with the CNS have been described in patients with NF1. For cxamplc, CNS tumors (optic gliomas) occur in up to $30 \%$ of children affected with NF1 (Huson et al., 1988; Lund and Skovby, 1991). Unidentified bright objects, visualized as bright spots in gadolinium-enhanced magnetic resonance imaging (MRI), are detected in the brains of $30-60 \%$ of patients; these may be small harmatomas

Received Aug. 12, 1992; revised Oct. 7, 1992; accepted Oct. 12, 1992.

This work was supported by NIH NS 28840 to N.R., who is also the recipient of a Harry Weaver Scholar award from the National Multiple Sclerosis Society, and by NIH NS 29218 and DC 00347 to M.T.S. We gratefully acknowledge Lisa Nissen, who derived the hybridomas secreting anti-neurofibromin, Maryellen Daston and Heidi Scrable for many helpful discussions, Matt Ennis for his help in refining light microscopic analyses, and Michael Lehman for assisting us in evaluating staining in the hypothalamus.

Correspondence should be addressed to Nancy Ratner at the above address. Copyright (c) 1993 Society for Neuroscience $0270-6474 / 93 / 131588-13 \$ 05.00 / 0$
(Duffner et al., 1989; Mulvihill et al., 1990). NF1 patients are also prone to a variety of mental deficits; $30-50 \%$ have specific disorders of cognition and memory (Dunn and Roos, 1988; Eldridge et al., 1989). In addition, many patients exhibit clumsiness (Dunn and Roos, 1988). The etiology of these significant and often disabling CNS manifestations is not known.

The gene that confers predisposition to NF1 was recently cloned and its cDNA sequenced (Viskochil et al., 1990; Wallace et al., 1990; Marchuk et al., 1991). Mutations in the NF1 gene have been defined in some patients (Cawthon et al., 1990; Viskochil et al., 1990; Wallace et al., 1990). Of the 2818 amino acids in the protein, a region of approximately 360 amino acids is homologous to mammalian GTPase activating protein (GAP) (Buchberg et al., 1990; Xu et al., 1990a), which stimulates the intrinsic GTPase activity of ras-p21. A fragment of neurofibromin containing the NF1 GAP-related domain (NFl-GRD) binds to and stimulates the GTPase activity of N-ras (Martin et al., 1990) and II-ras (Ballester et al., 1990) as do yeast IRA proteins (Tanaka et al., 1990a,b) and GAP itself (Marshall et al., 1989). This suggests that the homology hetween neurofibromin and GAP proteins has functional significance. This is further supported by the finding that introduction of NF1-GRD into IRA-deficient yeasts, which are incapable of cell division, complements these strains and restores normal proliferation (Ballester et al., 1990; Xu et al., 1990b). Ras initiates growth and/or differentiation signals in several cell types including neurons and glial cells (Bar-Sagi and Feramisco, 1985; Noda et al., 1985; Guerrero et al., 1986; Hagag et al., 1986; Ridley et al., 1988; Borasio et al., 1989). Ras is present in the CNS (Furth et al., 1987). Taken together, these findings suggest that neurofibromin may play a role in the regulation of ras or ras-like proteins in neurons and glia, as well as other cell types.

Insights into the function of neurofibromin and the etiology of the CNS manifestations of NF1 may be provided by knowledge of the neuroanatomical distribution and the types of cells expressing neurofibromin in the normal brain. We and others have previously shown that neurofibromin is a $220 \mathrm{kDa}$ protein highly enriched in the brain and spinal cord of adult rats (Hattori et al., 1991; Daston et al., 1992). Others have demonstrated that neurofibromin is expressed in the mouse brain (Buchberg, 1990; Gutmann et al., 1991). Within the spinal cord of both rat and human, neurofibromin is present in neurons and oligodendrocytes, but not in astroglial or microglial cells (Daston et al., 1992). The localization of neurofibromin in the brain is unknown. Thus, we have investigated the cellular, subcellular, and neuroanatomic distribution of neurofibromin in the adult rat brain. We show, for the first time, that neurofibromin is expressed preferentially in the dendrites of long-projection neurons, where it is localized to stacks of smooth membranous 
cisterns thought to be involved in $\mathrm{Ca}^{2+}$ regulation, and to small vesicles and multivesicular bodies that may be part of the endocytic pathway.

\section{Materials and Methods}

Preparation of antibodies. Polyclonal antibodies recognizing two TrpE fusion proteins containing amino acids $772-1085$ or $2435-2745$ of the human NFl sequence (nomenclature according to Marchuk et al., 1991) have been described previously (Daston et al., 1992). The same fusion proteins were injected at monthly intervals into $\mathrm{Balb} / \mathrm{C}$ mice $(30 \mu \mathrm{g} /$ mouse/injection). Three days after the fourth injection, the spleens were surgically removed from the mice and the splenocytes isolated and fused with P3X/63 Ag8.653 myeloma cells using standard protocols (Kohler and Milstein, 1976). Hybridomas were grown on 96-well plates under hypoxanthine aminopterin thymidine (HAT) selection. After 2 weeks, conditioned media from each well were assayed by an Elisa (Daston et al., 1992). Cells in wells that recognized the appropriate fusion protein more strongly than the inappropriate fusion protein or vector proteins were cloned by dilution. One antibody recognizing each fusion protein was cloned an additional time. Monoclonal antibodies were not useful for immunoprecipitation or Western blotting, but were used in immunostaining.

Immunoprecipitation. Extracts of cortex, medulla, pons, cerebellum, and diencephalon were made by surgically dissecting adult rat brains into these regions and homogenizing the regions in buffer containing $0.1 \%$ SDS and $1 \%$ Triton X-100 (TX100) (Daston et al., 1992). Immunoprecipitation of neurofibromin from $1 \mathrm{mg}$ of total protein, electrophoresis, and Western blot analysis were performed as previously described (Daston et al., 1992).

Preparation of tissue. Adult rats, $250-350 \mathrm{gm}$, were anesthetized with sodium pentobarbital and intracardially perfused at $80-100 \mathrm{ml} / \mathrm{min}$ with room temperature $0.9 \% \mathrm{NaCl}$ until clearing of the liver was observed (100-200 ml) and then with 1 liter of $4 \%$ paraformaldehyde, $0.1 \%$ glutaraldehyde, and $0.2 \%$ picric acid in $0.1 \mathrm{M} \mathrm{NaPO}_{4}, \mathrm{pH} 7.4(\mathrm{~PB})$ at $4^{\circ} \mathrm{C}$. Following perfusion, brains were surgically removed and placed in ice-cold perfusion fixative (100-200 ml/brain) for 4-24 hr. Postfixed brains were cryoprotected by equilibration in $20 \%$ sucrose in $\mathrm{PB}$ at $4^{\circ} \mathrm{C}$ for $24 \mathrm{hr}$ and then into cold $30 \%$ sucrose in PB. Brains were stored at $4^{\circ} \mathrm{C}$ in $30 \%$ cryoprotectant containing $0.02 \% \mathrm{NaN}_{3}$ for up to 2 weeks.

Immunohistochemistry. A total of 14 brains cut in coronal section, 2 in sagittal section, and 3 in horizontal section were evaluated. Fixed, cryoprotected brains were frozen and serially sectioned at $30-40 \mu \mathrm{m}$ on a sliding microtome; every third section was analyzed. The sections were rinsed in PB and then blocked overnight in $10 \%$ normal goat serum or $10 \%$ horse serum in PB containing $0.4 \%$ TX 100 . To minimize nonspecific interactions of the antibodies, primary antibodies were diluted in blocking buffer containing $10 \mu \mathrm{g} / \mathrm{ml}$ of bacterial protein extracts, prepared from bacteria transfected with vectors containing the fusion protein sequence in an antisense orientation. Primary antibodies were then applied for $48 \mathrm{hr}$; polyclonal antibodies were used at a concentration of $1 \mu \mathrm{g} / \mathrm{ml}$, and monoclonal antibodies were prepared by concentrating conditioned media 10 -fold in a Centricon 30 microconcentrator (Amicon, Danvers, MA). Sections were then incubated in $0.5 \% \mathrm{H}_{2} \mathrm{O}_{2}$ for 10 min and washed five times in PB with Triton. Biotinylated goat anti-rabbit or horse anti-mouse secondaries (Vector Labs, Burlingame, $\mathrm{CA}$ ) were diluted 1:250 in blocking buffer and applied for $4 \mathrm{hr}$ at room temperature on an orbital shaker. Samples were washed three times, and staining was visualized with standard HRP methods using a Vectastain kit (Vector Labs, Burlingame, CA).

Immunoelectron microscopy. Adult rats were fixed by perfusion as above, except that glutaraldehyde was increased to $0.2 \%$ and fixative was at room temperature. After sucrose infiltration, $50 \mu \mathrm{m}$ sections of cerebellum were cut on a freezing microtome, washed in $0.1 \%$ TX 100 in $\mathrm{PB}$ for $15 \mathrm{~min}, 0.1 \mathrm{~m}$ glycine for $30 \mathrm{~min}, 0.5 \% \mathrm{H}_{2} \mathrm{O}_{2}$ in $0.1 \%$ TX100 in $\mathrm{PB}$ for $15 \mathrm{~min}, 0.1 \% \mathrm{TX} 100$ in $\mathrm{PB}$ for $15 \mathrm{~min}$, and $10 \%$ normal goat serum in PB for $1 \mathrm{hr}$, and then stained as above for neurofibromin, using a polyclonal antibody recognizing amino acids $2435-2745$ [PC (2435-2745)]. Reactions were controlled using a glucose-oxidase kit (Sigma), sections were washed in $0.1 \%$ TX100 in PB and then postfixed in $2 \% \mathrm{OsO}_{4}$ in water for $45 \mathrm{~min}$, dehydrated through a graded series of alcohols, and flat embedded in Epon 810 . Semithin $(1 \mu \mathrm{m})$ sections were taken until reaction product became visible, and then silver gray sections were analyzed on Formvar-coated grids in a JOEL 100 electron microscope at $60 \mathrm{kV}$.

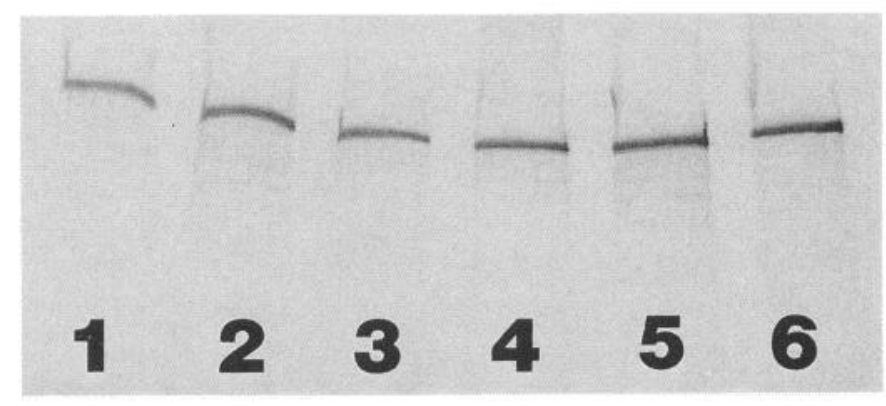

Figure 1. Neurofibromin is expressed throughout the adult rat brain. Detergent extracts from major anatomical regions of adult rat brain were immunoprecipitated using PC (2435-2745). Precipitated protein was electrophoresed and visualized by Western analysis using PC (7721085). Lanes: 1 , cerebellum; 2 , medulla; 3 , pons; 4 , midbrain; 5 , diencephalon; and 6 , cortex. A single $220 \mathrm{kDa}$ protein was precipitated from all regions, indicating that neurofibromin is distributed throughout the brain. The apparent molecular weight of neurofibromin has previously been estimated at $220 \mathrm{kDa}$ (Daston et al., 1992). The similar intensities of the bands suggest that the amount of neurofibromin per milligram of protein is constant throughout the major regions of the brain.

\section{Results}

\section{Regional distribution of neurofibromin in the rat brain}

Adult rat brains were dissected into cortex, diencephalon, cerebellum, midbrain, pons, and medulla. Detergent extracts of each sample were prepared and neurofibromin immunoprecipitated using PC (2435-2745). Precipitated protein was analyzed by Western analysis using a second polyclonal antibody, PC (772-1085). The specificity of these antibodies has been demonstrated previously (Daston et al., 1992). As illustrated in Figure 1 , a single $220 \mathrm{kDa}$ band was observed in all brain regions. The relative abundance of neurofibromin per milligram of extracted protein was similar for all the major anatomical subdivisions of the brain; the abundance of neurofibromin in the brain has been shown to be $0.004 \%$ of total protein (Daston et al., 1992).

\section{Immunohistochemical localization of neurofibromin in the adult rat brain}

We used two polyclonal antibodies as well as two monoclonal antibodies raised against two different domains of neurofibromin (Daston et al., 1992) to stain adult rat brain sections. All antibodies gave similar staining patterns, but the most robust staining was observed with PC (2435-2745). Figure 2 shows an example of staining of layer $\mathrm{V}$ in the rat cerebral cortex using the two monoclonal antibodies (Fig. 2E,F) and PC (2435-2745) (Fig. $2 A, D$ ). Staining was abolished when the antibodies were preabsorbed with their appropriate fusion protein; an example of staining following preabsorption of PC (2435-2745) is shown in Figure $2 B$. Use of preimmune sera resulted in nonspecific staining of the sections, which was not diminished in intensity when preabsorbed with either fusion protein (not shown). Because of the similarity of the staining patterns of the three antibodies raised against two different domains of neurofibromin, we conclude that the staining pattern reflects the authentic distribution of neurofibromin.

\section{Cerebral cortex}

The most prominent neurofibromin staining in cerebral cortex was in apical dendrites of pyramidal cells. The thicker dendrites 
A A Wha 1 . 17.

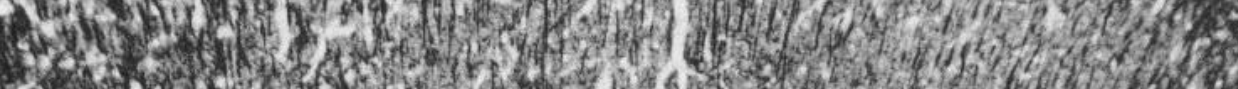

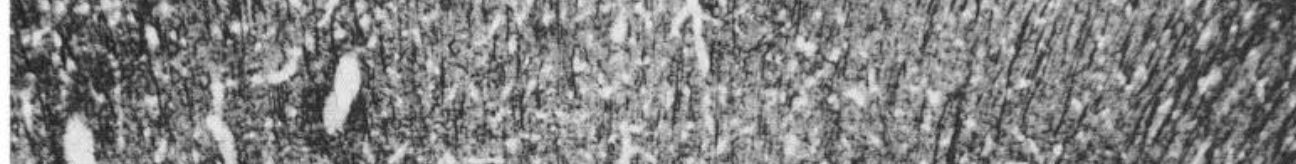
1 w n W.m

A b.

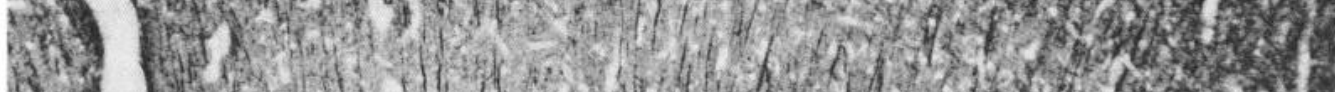

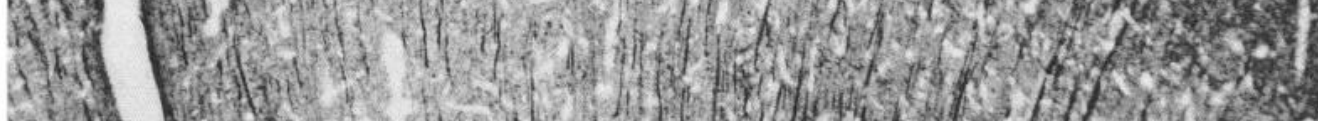

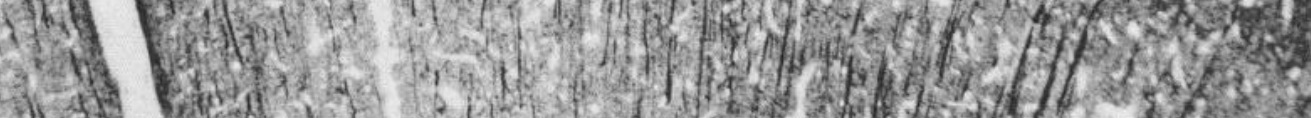

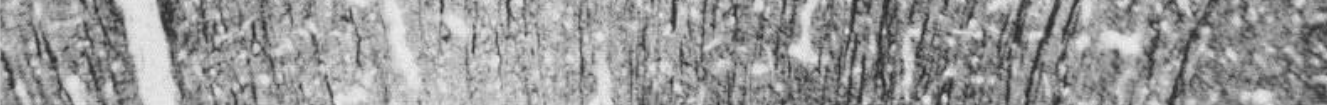

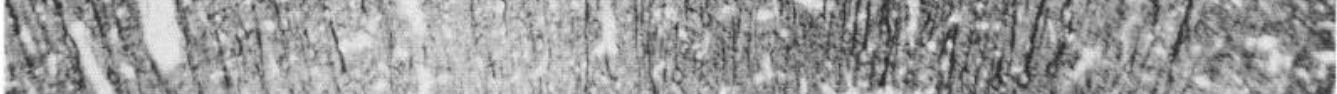

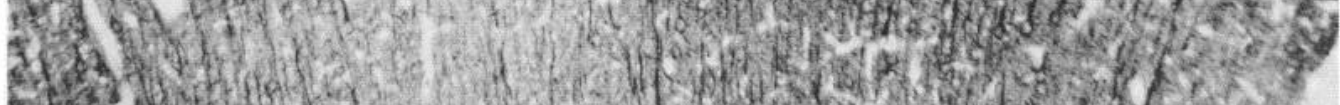

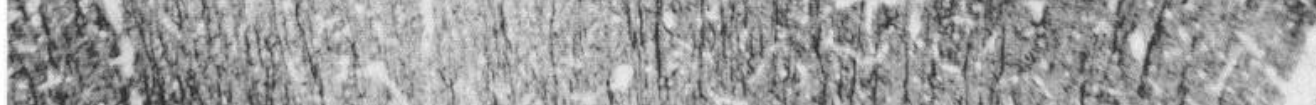
1.120
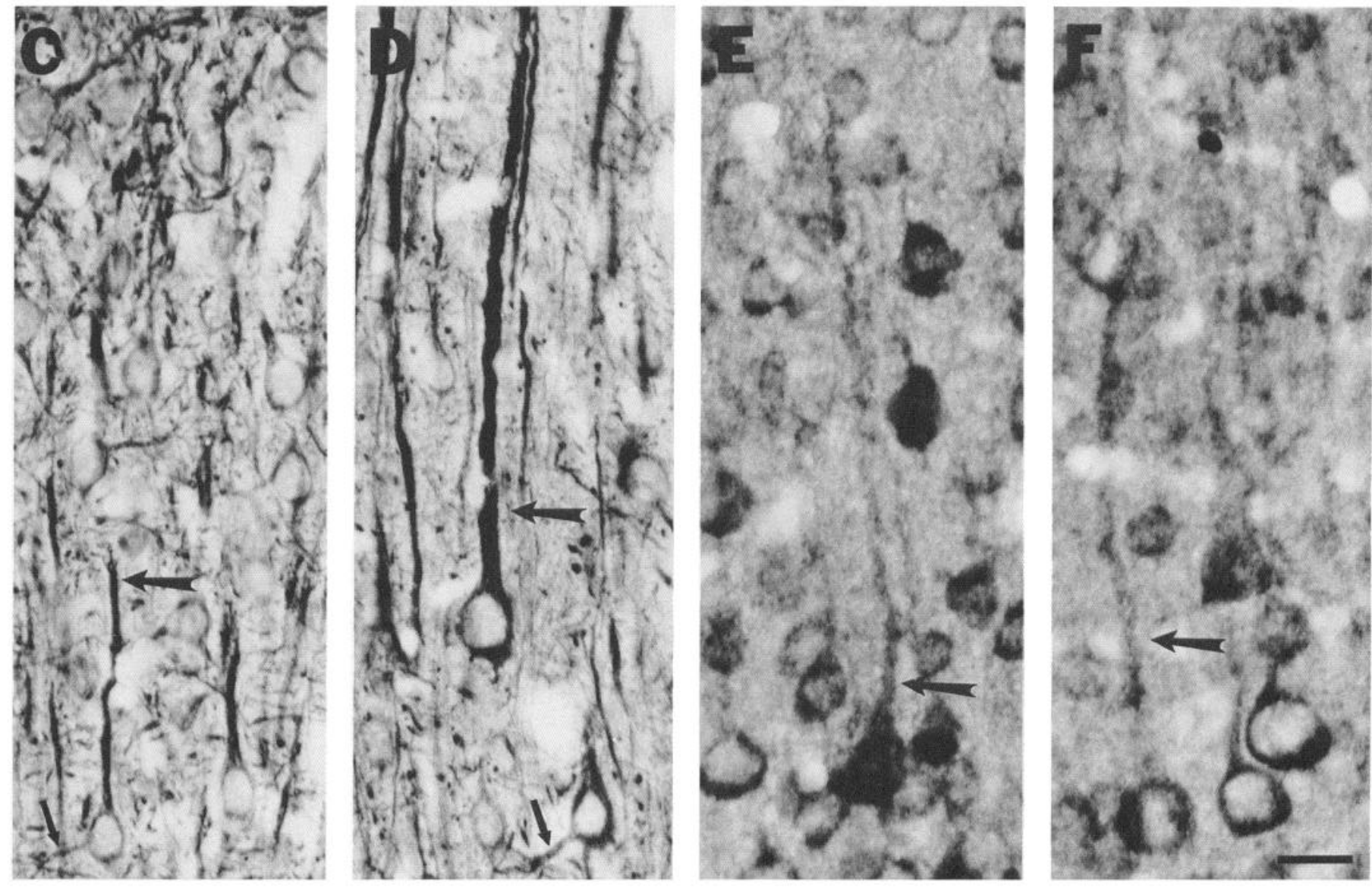
of the largest pyramidal cells, those in layer $\mathrm{V}$, showed the most intense staining (Fig. $2 \mathrm{C}$ ). The entire length of the apical dendrites could be visualized as they coursed toward the pial surface. Apical dendrites give rise to smaller dendrites that project laterally and are called oblique branches; these easily identifiable higher-order branches were less intensely stained than the thicker primary dendrites. A meshwork of fine processes coursing throughout all layers of cortex was also obscrved. These fine processes were densest in layers I, II, and III (Fig. 2C), and had the characteristic organization of the terminal tufts of apical dendrites. Fine processes were also stained in layers IV and V. These may be oblique branches of apical dendrites from pyramidal cells in layers IV and V and/or basal dendrites of neurons in these or more superficial layers. Stained basal dendrites could only be traced $30-50 \mu \mathrm{m}$ from their point of origin on the neuronal cell body, although they project an average of $185 \mu \mathrm{m}$ (Winkelmann et al., 1973) in rat layer $V$ neurons.

Neurofibromin expression was also observed in the perikaryon of pyramidal neurons (Fig. 2C,D) surrounding the large unstained nucleus. The large (30-50 $\mu \mathrm{m}$ in diameter) pyramidal neurons, of layer V, were the most intensely stained (Fig. 2D), but significant staining of pyramidal neurons with smaller (10$25 \mu \mathrm{m}$ in diameter) cell bodies in all other layers was also observed (Fig. 2C).

The piriform cortex and hippocampus, examples of archeocortex, also showed prominent neurofibromin immunoreactivity. As in the neocortex, staining was entirely restricted to the dendrites and perikarya of pyramidal neurons, was most prominent in the apical dendrites and cell bodies, and was present in fine distal dendrites.

Neurofibromin is preferentially expressed in the dendrites of neuronal subsets. In the CA fields in the hippocampus, staining was enriched in the apical dendrites of pyramidal cells (Fig. $3 A$ ). In sharp contrast, the granule cells of the dentate gyrus, which elaborate an extensive dendritic array in the dentate molecular layer, exhibited little dendritic neurofibromin staining (Fig. 3B). Multipolar neurons, presumably basket cells (interneurons), deep to the pyramidal cell layer in Ammon's horn were stained.

\section{Thalamus, basal ganglia, and brainstem}

Many neurons were stained in the brainstem, basal ganglia, and thalamus; most nuclei contained immunoreactive neurons; examples are shown in Figure 4. Stained neurons ranged in size from 10 to $50 \mu \mathrm{m}$ in diameter and possessed a multipolar morphology. As in the neocortex and hippocampus, staining was enriched in cell bodies and processes emanating from cell bodies.

Not all neurons within subcortical nuclei were stained. In several thalamic nuclei, the percentage of unstained neurons was estimated in cresyl violet-counterstained sections; neurons were identified by the presence of euchromatic nuclei with prominent nucleoli. The majority of neurons demonstrated neu- rofibromin immunoreactivity, but $30 \%$ were unstained. Thus, as in the cortex, only a subpopulation of neurons expressed neurofibromin.

\section{Hypothalamus}

The cell bodies of neurons in most hypothalamic nuclei were unstained; unstained nuclei included the paraventricular, ventromedial, and suprachiasmatic nuclei as well as all the nuclei in the lateral hypothalamic area (not shown). The only nucleus that contained immunostained neurons was the supraoptic nucleus, in which staining was restricted to cell bodies and dendrites of most, if not all, neurons. The majority of the staining in the hypothalamus was of fine processes in the neuropil in the periventricular and lateral hypothalamic areas. Throughout these areas, weakly stained neuronal cell bodies were occasionally observed; stained neurons were not clustered and their positions did not correspond to known cytoarchitectonic boundaries.

\section{Cerebellum}

In the deep nuclei of the cerebellum, large neurons with cell bodies $25-50 \mu \mathrm{m}$ in diameter were heavily stained (Fig. $5 \mathrm{C}$ ). The staining was restricted to the cell body and proximal processes. Some of the processes originating from these neurons may be axons. Multiple processes extend from each cell soma, however, and therefore, at least the majority of processes are dendrites. Not all the neurons in the deep nuclei were stained. Counterstaining with cresyl violet revealed neurons, as identified by the presence of euchromatic nuclei with prominent nucleoli, which contained no neurofibromin immunoreactivity (Fig. $5 D$ ). Approximately $70 \%$ of neurons showed prominent neurofibromin staining; $30 \%$ were not detectably reactive. Glial and endothelial cells identified by small, highly heterochromatic nuclei were not stained by anti-neurofibromin antibodies.

Neurofibromin staining in the cerebellar cortex was highly enriched in the cell bodies and dendrites of the Purkinje cells, the output neurons of the cerebellum. The majority of the extensive dendritic arbor of the Purkinje cells was intensely stained in sections cut perpendicular to the pial surface (Fig. $5 A, B$ ). Primary, secondary, tertiary, and quaternary branches of the dendrites were stained, but the fine terminal branches were not detectably labeled. Neurofibromin immunoreactivity was also observed in the cell bodies of the Purkinje cells; the staining was homogeneous over the entire cell body except for the nucleus, which was clear. The proximal $50 \mu \mathrm{m}$ of Purkinje cell axons demonstrated weak reactivity. Occasionally, the cell body and dendrites of Golgi neurons in the granular layer were weakly stained. A meshwork of fibers surrounding granule cells was very weakly reactive in some preparations, suggesting that granule cell dendrites may contain some neurofibromin. Other neuronal cell types in the cerebellum including basket and stellate neurons located between the monolayer of the Purkinje cells and the pial surface were unstained.

Figure 2. Neurofibromin staining in the neocortex is enriched in the apical dendrites and peripheral cytoplasm of pyramidal neurons. Immunoperoxidase staining of free-floating coronal sections of rat cortex using polyclonal and monoclonal antibodies made against different domains of neurofibromin was performed as described in Materials and Methods. A, A low-magnification view of neocortex stained with PC (2435-2745) demonstrating intensely stained apical dendrites and perikarya of pyramidal cells in all cortical layers. $B$, A similar section of neocortex after preabsorbing against the $2435-2745$ fusion protein. High-magnification reviews of layers II and III $(C)$ and layer V $(D)$ using the same polyclonal antibody demonstrate the staining of the apical (large arrows) and basal (small arrow) dendrites of pyramidal cells. Cell body staining is also evident, but nuclei are unstained. High-magnification views of layer $V$ in sections stained with monoclonal antibodies made against the $2435-2745(E)$ and 772-1085 $(F)$ domains of neurofibromin demonstrate similar staining patterns. Scale bars: $A$ and $B, 200 \mu \mathrm{m} ; C-F, 20 \mu \mathrm{m}$. 


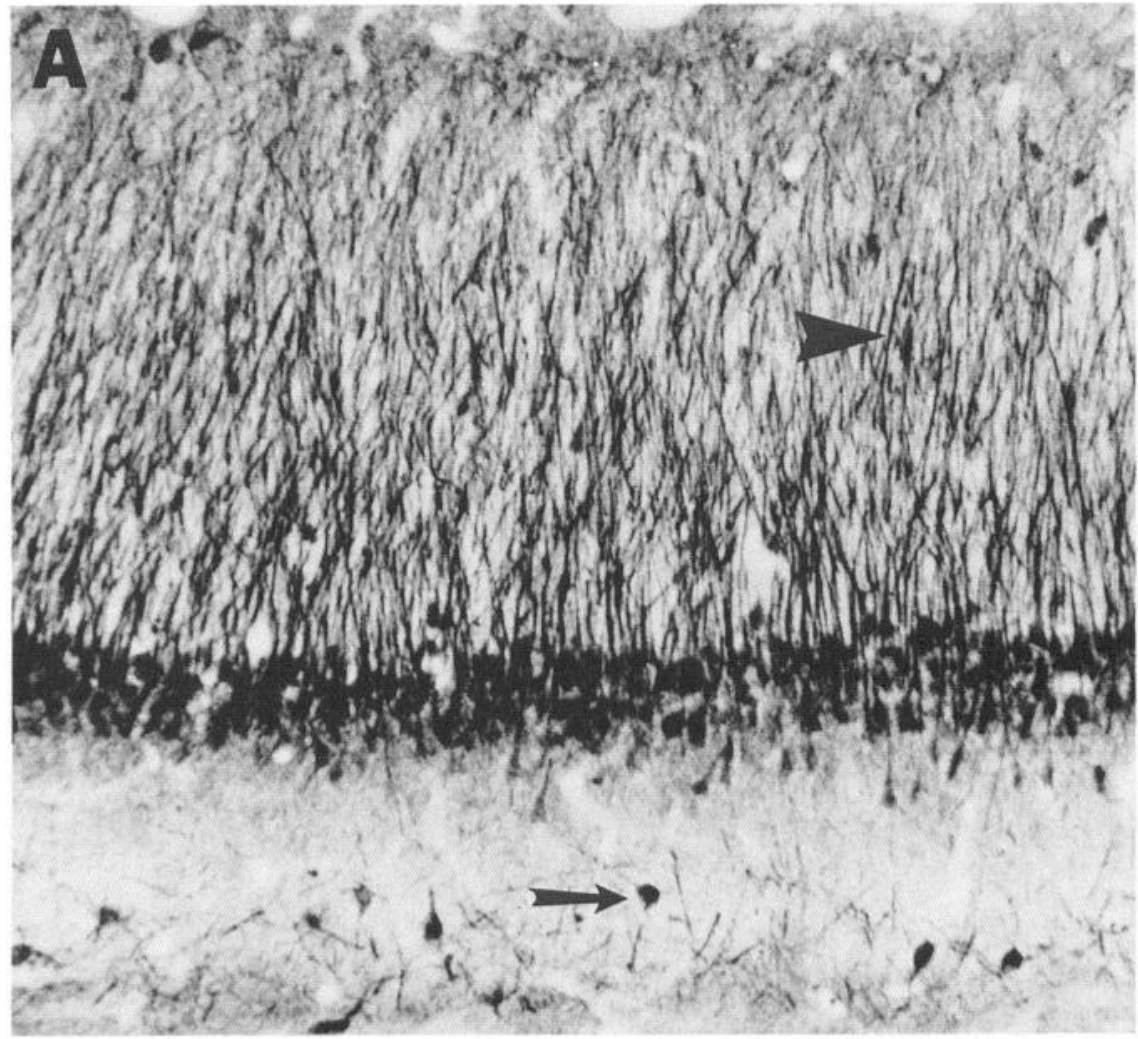

Figure 3. Neurofibromin is preferentially expressed in subsets of dendrites. Coronal sections through the hippocampus were stained for neurofibromin with PC (2435-2745). Low-magnification view of Ammon's cortical area 1 (A) shows the intense labeling of apical dendrites (arrowhead) of the pyramidal cells. Basal dendrites are weakly stained. Arrow points to stained neurons, presumably interneurons, deep to the pyramidal cells. $B$ is a low-magnification view of the dentate gyrus. Arrowhead points to the weakly stained, extensive dendritic array of granule cells. Comparison of the two hippocampal regions demonstrates the heterogeneity of neurofibromin staining in dendrites. Scale bar, $10 \mu \mathrm{m}$.

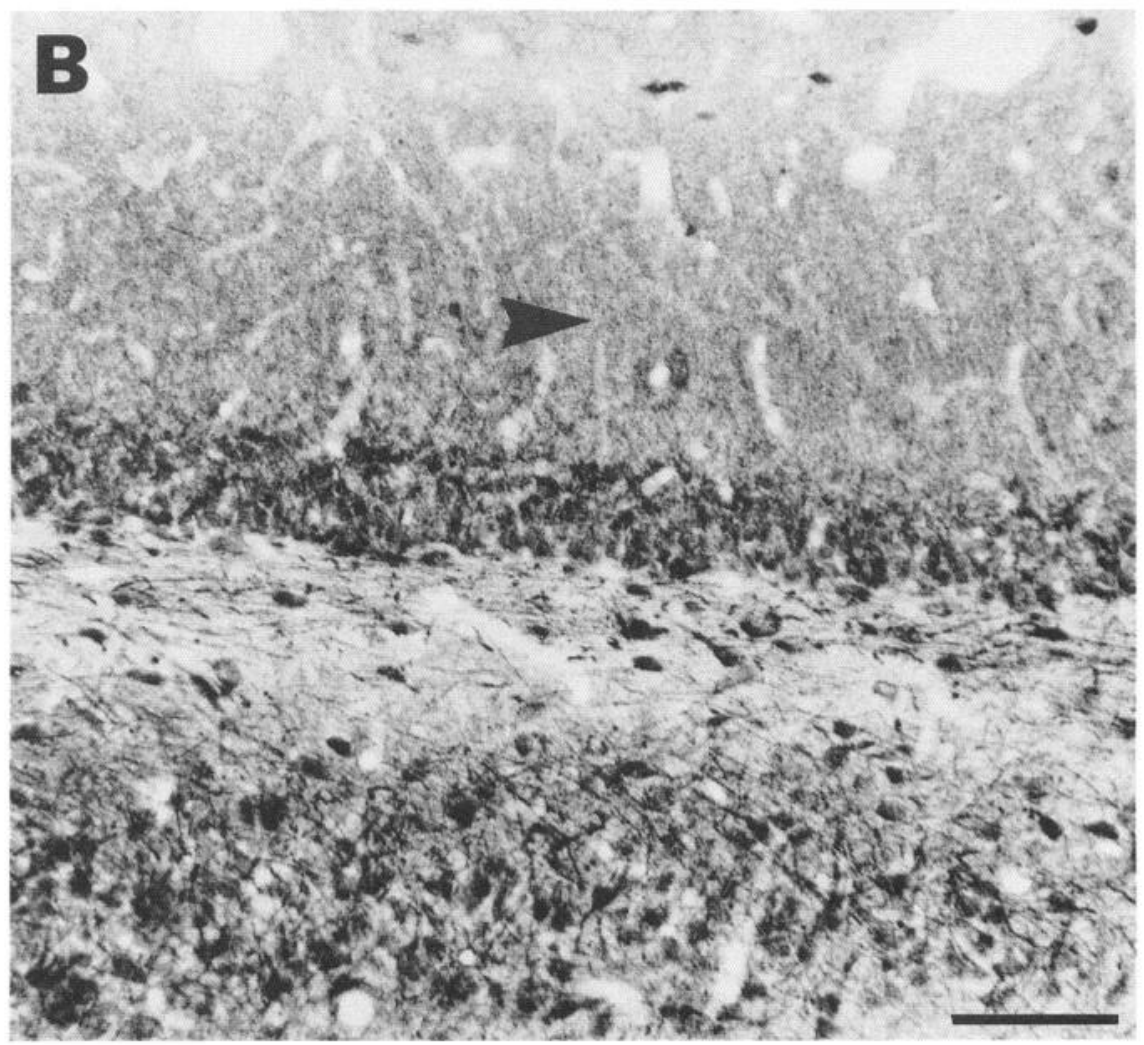

Figure 4. Neurofibromin staining in subcortical brain regions. In many nuclei, neurofibromin staining was enriched in cell bodies and processes $(A, B, D-G)$. In other regions, staining of processes was much more intense than that of cell bodies $(C, H)$. $A$, ventroposterolateral nucleus of the thalamus; $B$, reticular nucleus of the thalamus; $C$, anterior hypothalamic area; $D$, supraoptic nucleus of the hypothalamus; $E$, caudate putamen; $F$, red nucleus; $G$, pontine reticular nucleus; $H$, nucleus ambiguus. Scale bar, $50 \mu \mathrm{m}$. 

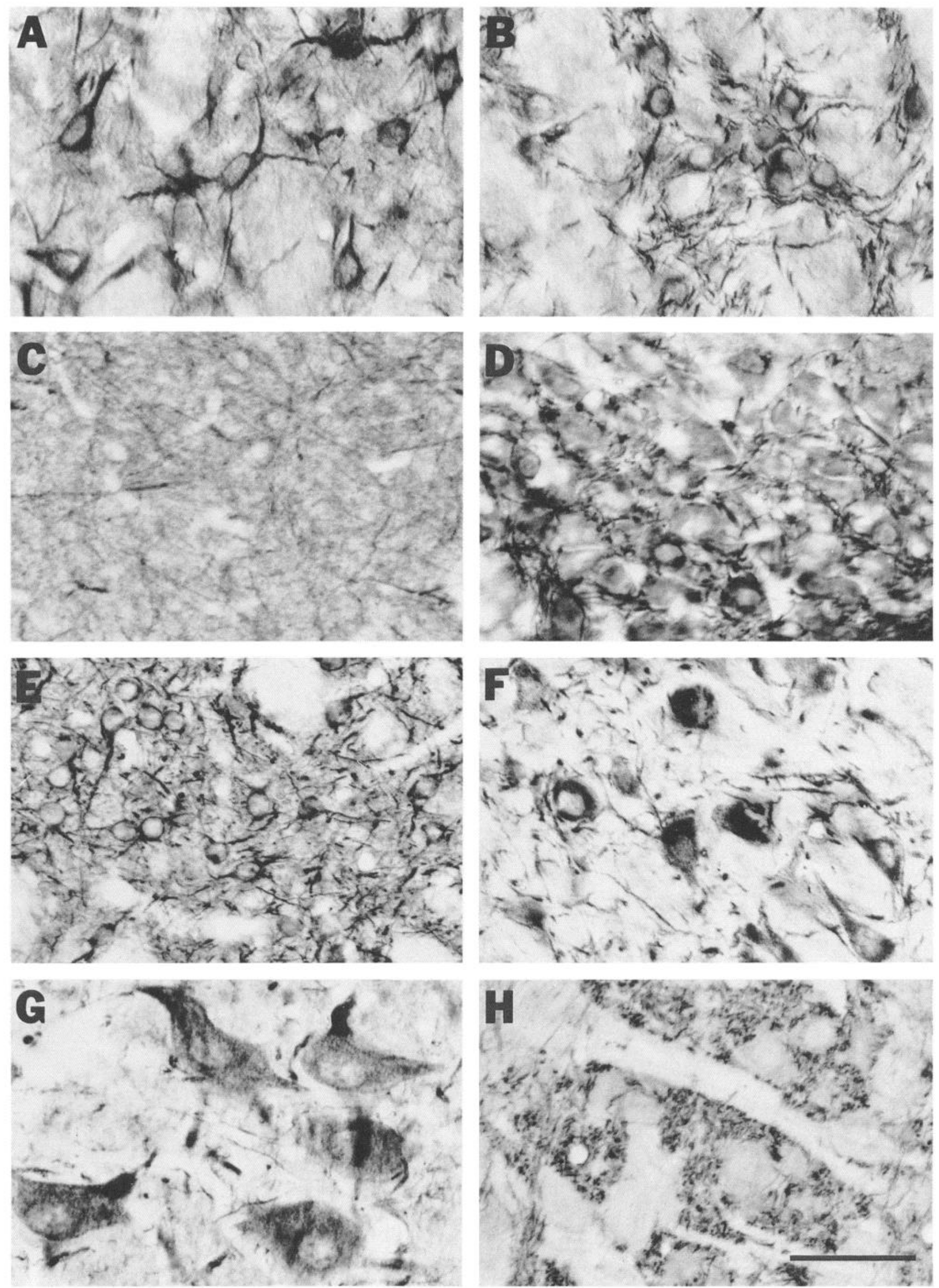
Figure 5. Staining of the cerebellum demonstrates that neurofibromin is enriched in Purkinje cells. Coronal sections through the cerebellum were stained with PC (2435-2745). A, A lowmagnification view through the folia of the cerebellum shows the absence of staining in the white matter $(w)$, and intense staining of Purkinje cells. White arrow points to a Golgi cell stained in the granular layer. $B$, A high-magnification view of Purkinje cell staining. Staining was enriched in the dendritic tree and cell soma, but nuclei were unstained (arrow) (other nuclei appear stained in this illustration because of the thickness of the section). A weakly stained axon (arrowhead) is indicated. $C$ is a section through a deep cerebellar nucleus stained with PC (2435-2745) and counterstained with cresyl violet. The picture was taken with a blue filter, which highlights peroxidase precipitate and conceals the blue product of the Nissl counterstain. Arrowheads point to neurofibromin-positive neurons; arrows indicate neurofibromin negative neurons. $D$ shows the same section as $C$ photographed without the blue filter. Large neurofibromin-negative neurons are revealed by the cresyl violet counterstain (arrows). Arrowheads point to the neurofibromin-positive cells shown in $C$. Small dense nuclei of glia are also visible. Scale bars: $A, 100 \mu \mathrm{m} ; B-D, 25$ $\mu \mathrm{m}$.
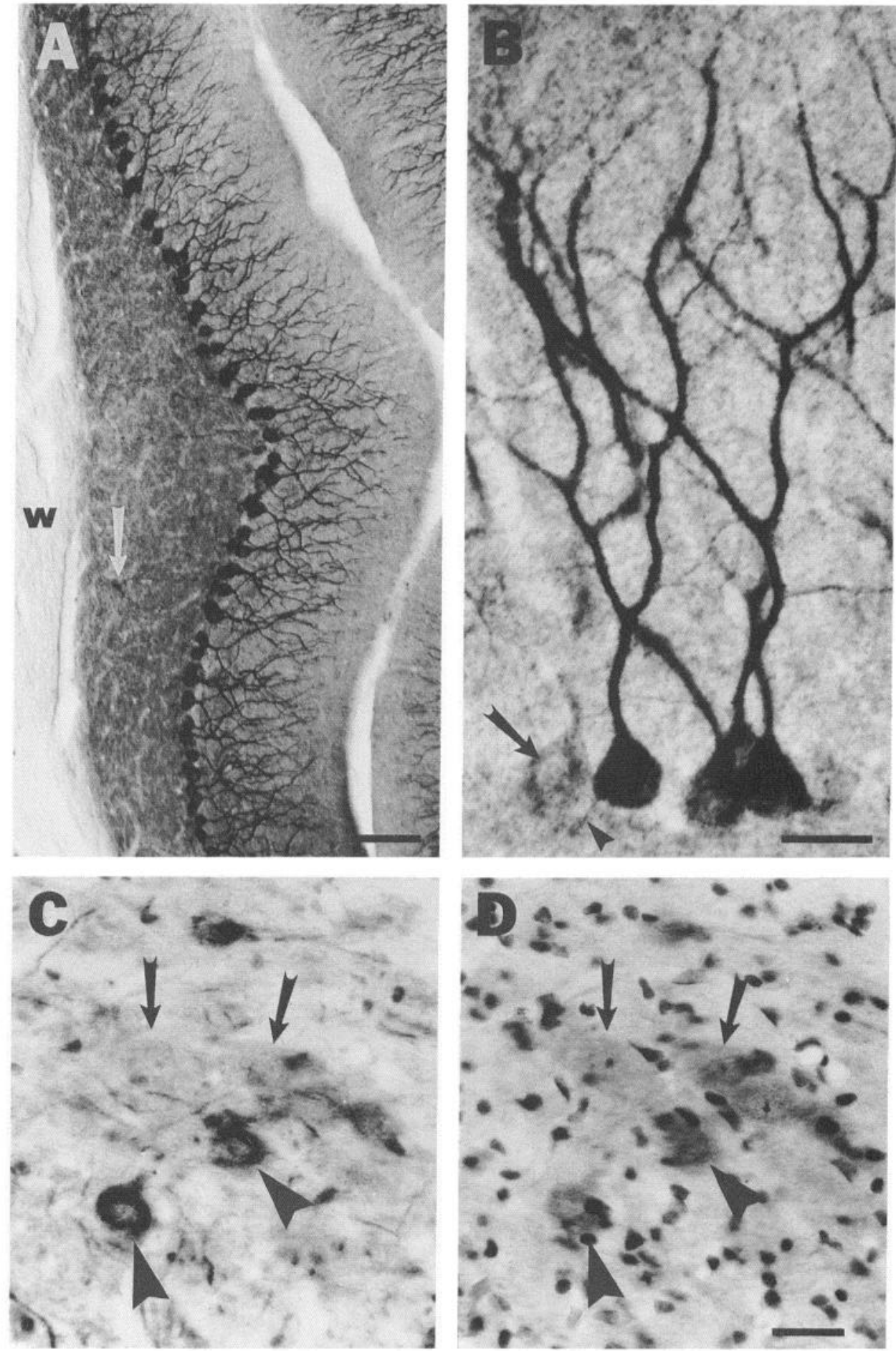

\section{Glia}

Neurofibromin immunoreactivity is prominent in oligodendrocytes in the adult rat spinal cord (Daston et al., 1992). Oligodendrocytes were also stained in the brain (not shown). There was no evidence of neurofibromin immunoreactivity in astrocytes, microglia, or endothelial cells anywhere in the brain.

Axons

The majority of axons were stained in the brain. For example, weakly stained axons were observed as they originated from
Purkinje cell bodies in the cerebellum (Fig. $4 B$ ), and axons were stained in white matter tracts (not shown). The axonal staining was always less intense than that observed in cell bodies and in dendrites; in many tracts axonal staining could be detected only in thin $(2 \mu \mathrm{m})$ sections.

\section{Ultrastructural localization of neurofibromin}

To define the subcellular localization of neurofibromin, preembedding immunoperoxidase electron microscopy was carried out. The cerebellum was selected for analysis since the most robust staining at the light microscope level was detected in 
Purkinje cells. Figure $6 \mathrm{~A}$ shows low-magnification electron micrographs of the cell body and proximal dendrite of a Purkinje cell stained by anti-neurofibromin, in which reaction product is visible in small patches in the cell body and is intense in the proximal dendrite. Even at low magnification, it was evident that the plasma membrane, nuclear envelope, mitochondria, and rough endoplasmic reticulum were not detectably stained. No rcaction product was detected when antibody was preabsorbed with fusion protein prior to staining (Fig. $6 B$ ).

At higher magnification, reaction product was observed on tubulovesicular profiles and membranous stacks in the cell body (Fig. 7A-C). These profiles are characteristic of the smooth endoplasmic reticulum of Purkinje cells (Rosenbluth, 1962; Morales and Duncan, 1966; Takahashi and Wood, 1970). Reaction product was not associated with the plasma membrane, nuclear membrane, Golgi apparatus, or rough endoplasmic reticulum (not shown). Some staining of mitochondria was seen, but only when adjacent to heavily labeled cisternal stacks or membrane vesicles (Fig. 7C); this was most likely diffused from nearby membrane stacks.

Reaction product in dendrites was so heavy as to obscure identification of labeled structures. To analyze the staining of dendritic organelles, semiserial sections were analyzed. At progressivcly decper levels of each block, staining diminished and it became possible to detect specific staining of cisternal stacks (Fig. $7 E$ ). For comparison, a proximal dendrite from a section stained with preabsorbed antibody is shown in Figure $7 F$. In stained dendrites, some cisternal stacks were stained heavily and others appeared less intensely stained or unlabeled (Fig. $7 C$ ). Vesicles and multivesicular bodies were sometimes, but not always, stained. In addition to staining of membranous cisterns, multivesicular bodies, and small vesicles, diffuse staining of the cytoplasm, cytoskeleton, and mitochondria was observed. This may be a product of diffusion of the reaction product, or may represent the presence of a pool of soluble neurofibromin in dendrites.

\section{Discussion}

\section{Neurofibromin in neurons}

Our results support the hypothesis that the primary defect that leads to the development of the diverse CNS manifestations of type 1 neurofibromatosis is in the neuron. The subset of neurons intensely labeled by anti-neurofibromin antibodies does not appear to correlate with the distribution of any of the major neurotransmitters, or with a particular sensory or motor system. Rather, neurofibromin is expressed primarily in large neurons whose axons project long distances. For example, in the cerebellum, only Purkinje cells were heavily stained with anti-neurofibromin antibodies. Similarly, only pyramidal cells were stained in the cortex; nonpyramidal and stellate cells were unstained. However, rare interneurons also express neurofibromin; these include occasional Golgi cells of the cerebellum and hippocampal neurons deep to pyramidal cells, which have the morphology of basket cells. In the thalamus, basal ganglia, and brainstem, neurofibromin was also expressed by only subpopulations of neurons; the neurons labeled in these regions may be mainly those that project axons long distances. Based on the staining patterns in the cortex and cerebellum, where the cytoarchitecture and basic circuitry have been definitively established, it seems plausible that stained neurons in the thalamus, basal ganglia, and brainstem are mainly projection neurons rather than interneurons. Further evaluation of this hypothesis will require double labeling with anti-neurofibromin and retrograde tracers.

NF1 patients often exhibit learning disabilities and clumsiness. Intense neurofibromin staining is present in the cortex and hippocampus, structures involved in cognition and memory, and in the cerebellum, the structure responsible for coordination of motor movements. Defects in output neurons have the greatest potential to disrupt the normal function of specific brain regions because these neurons are the nodal points for information flow out of these regions. Output neurons receive integrated synaptic inputs and transmit an appropriate response. Thus, it is reasonable that NF1 patients who have only one normal NF1 allele might exhibit CNS dysfunction. While these inferences are currently highly speculative, they may provide working hypotheses for future investigations of specific brain areas in NF1-affected individuals and normal human controls.

\section{Ultrastructural analysis of neurofibromin distribution}

Light microscopic analysis suggested that neurofibromin was primarily expressed by neurons in the CNS. Large, presumably projection neurons were the most heavily stained, and in the majority of neurofibromin-positive neurons, staining was preferentially heavy in dendrites. This suggests that neurofibromin is selectivcly enriched in dendrites of CNS projection neurons. At the ultrastructural level, neurofibromin is preferentially associated with smooth endoplasmic reticulum and multivesicular bodies. These organelles are present in all compartments of neurons-soma, axon, terminals, and dendrites. Based on these findings, it is possible that the preferential staining of dendrites of large neurons observed at the light microscope level is the resull of large neurons and dendrites having a higher absolute content of smooth endoplasmic reticulum and thus of neurofibromin. The apparent lack of neurofibromin in many neurons and in small dendritic processes may reflect a relatively lower concentration of these membranes rather than a specificity of neurofibromin for large neurons. To date our ultrastructural observations are limited to Purkinje cells. In future studies it will be necessary to examine small neurons and fine-caliber neuronal processes to determine if neurofibromin is present. For the present it is safe to say that neurofibromin is selectivcly enriched in large neurons. Whether this reflects specificity or a concentration effect remains to be determined.

Our ultrastructural results indicate that neurofibromin is preferentially associated with intracellular membranes. Several groups have carried out subcellular fractionation to localize neurofibromin. The results of these studies have been inconclusive, in that while some have found neurofibromin entirely membrane bound (DeClue et al., 1991; Hattori et al., 1991), others have found neurofibromin in both membrane and cytosolic fractions (Bollag and McCormick, 1991). Under the conditions of fixation and permeabilization used in our study, soluble neurofibromin might be removed from sections and thus not detected, or be present at levels too low to be detected in the cell body of Purkinje cells. It is also possible that some of the diffuse staining in dendrites might reflect the presence of soluble neurofibromin.

\section{Functional implications of neurofibromin localization}

Neurofibromin immunoreactivity was not associated with the plasma membrane. This result was surprising, since it has been shown that neurofibromin can modulate the activity of ras (Ballester et al., 1990; Martin et al., 1990), and ras is targeted 

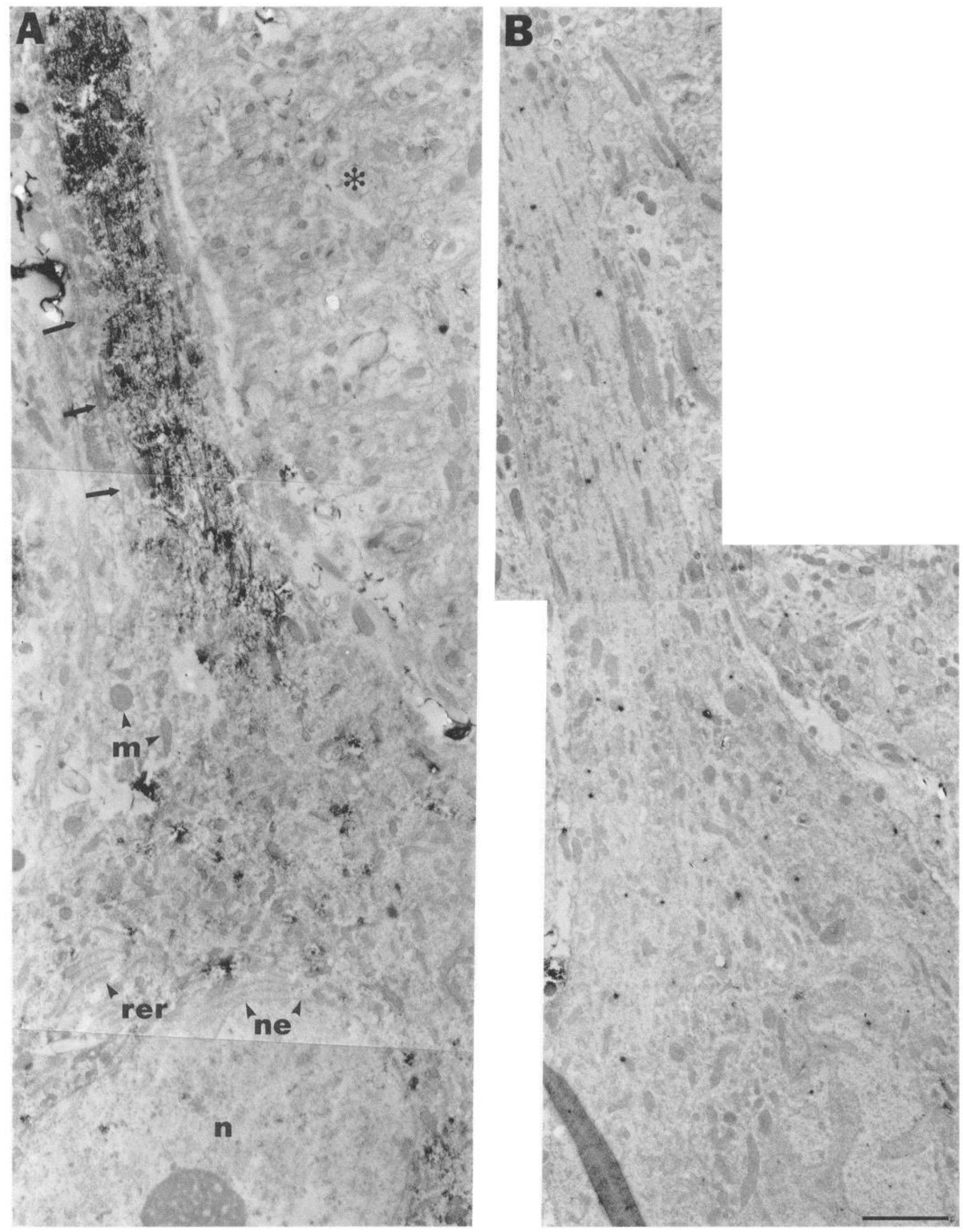

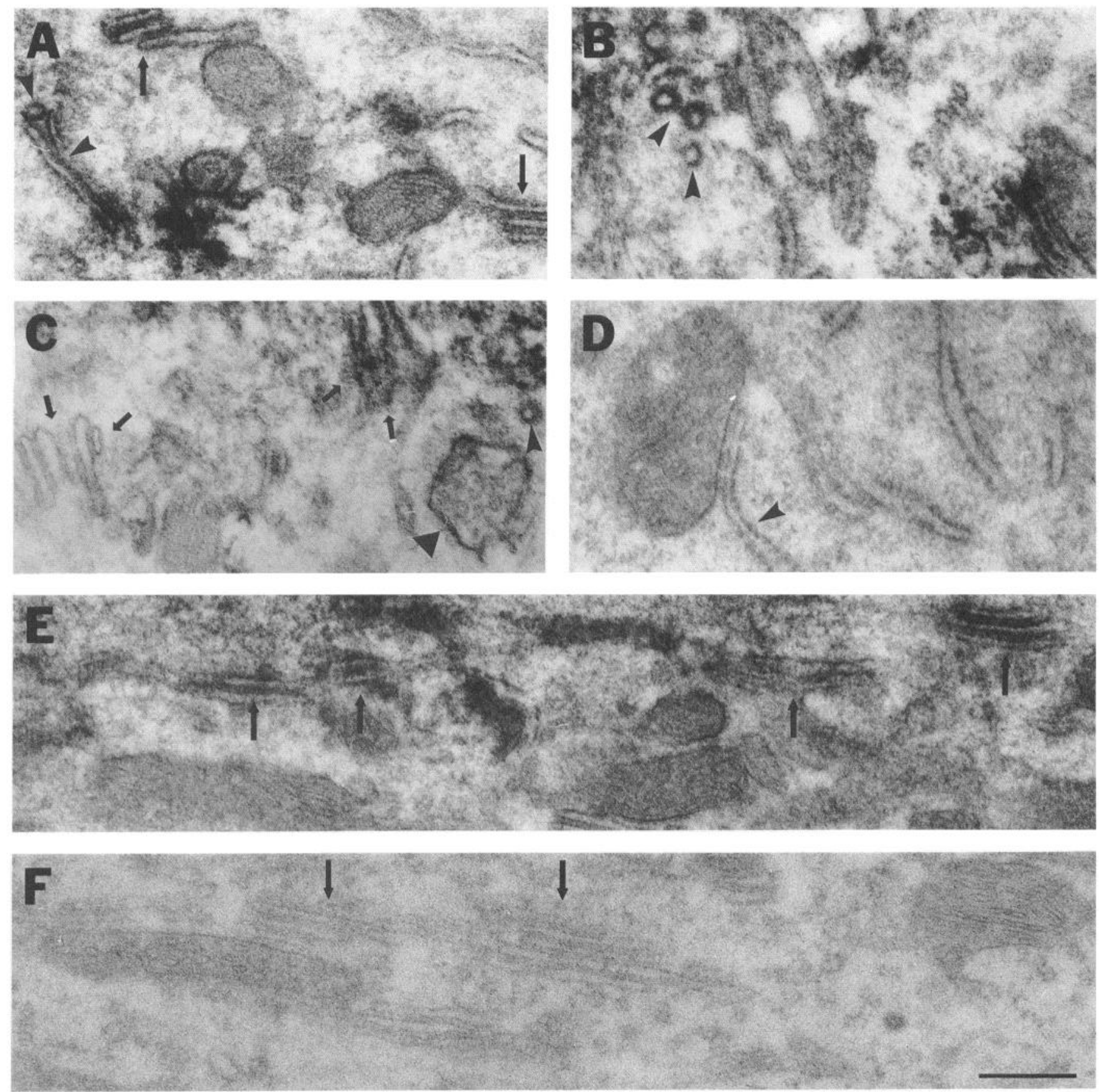

Figure 7. Ultrastructural localization of neurofibromin in the cell body and dendrites of Purkinje cells. Peroxidase reaction product covers membranous elements in the cell body $(A-C)$ and dendrite $(E)$. No reaction product is present in section preabsorbed using fusion protein $(D, F)$. In each panel, cisternal stacks are indicated by large arrows and small arrowheads point to vesicles and tubulovesicular membranes. In $C$, the large arrowhead points to a stained multivesicular body and the paired small arrows to stained (right) and unstained (left) membrane stacks. Scale bar, $0.3 \mu \mathrm{m}$.

to the plasma membrane (Willingham et al., 1980; Hancock et al., 1991). Our data thus suggest that, in neurons, neurofibromin may not interact with plasma membrane associated ras-p21. This might be because in neurons neurofibromin interacts with proteins that are not in the ras superfamily, or that it interacts with ras-like proteins that are not plasma membrane associated. Alternatively, under certain conditions neurofibromin might be targeted to the plasma membrane, where it could interact with

Figure 6. Ultrastructural localization of neurofibromin in Purkinje cells. Preembedding immunoperoxidase staining of sections of cerebellum with PC (2435-2745) shows dark reaction product in the electron micrograph showing the cell body and proximal dendrite of a Purkinje cell $(A)$. Arrows delineate the unstained plasma membrane. Mitochondria $(m)$ are also unstained, as is the nucleus $(n)$, nuclear envelope (ne), and rough endoplasmic reticulum (rer). Surrounding neuropil is also unstained $(*)$. For comparison, a Purkinje cell stained with the same antibody preabsorbed with fusion protein (2435-2745) is shown in $B$. No reaction production is visible. Scale bar, $2 \mu \mathrm{m}$. 
ras. Moran et al. (1991) have shown that GAP, which is mainly cytosolic, can move to the plasma membrane in mitogen-stimulated cells. An additional possibility is that, on stimulation of neurons by specific extracellular signals, membrane-associated ras (or ras-like proteins) dissociates from the plasma membrane and interacts with neurofibromin. Rap1A (KREV-1) protein, homologous to ras, translocates from intracellular granules to the plasma membrane on stimulation of neutrophils with phorbol myristate acetate (Quinn et al., 1992), and, following activation, the ras-related molecule RAP1B translocates from membranes (probably the plasma membrane) to the cytoskeleton (Fischer et al., 1990). Since ras activation leads to proliferation in some cell types and differentiation in others, such as neurons, our results do not preclude the possibility that neurofibromin will show a distinct pattcrn of localization in non-ncural cells or immature neurons.

The membranous stacks labeled by anti-neurofibromin in the cell body and in dendrites of Purkinje cells have been described as multilaminated bodies (Morales and Duncan, 1966), lamellar bodies (Herndon, 1964), and cisternal stacks (Villa et al., 1991). These stacks of smooth endoplasmic reticulum are often found in close proximity to mitochondria (Takahashi and Wood, 1970; Fiori and Mugnaini, 1981); at least some are continuous with the rough endoplasmic reticulum (Herndon, 1963; Satoh et al., 1990), and they are enriched in proximal dendrites (Yamamoto et al., 1991), as is neurofibromin immunoreactivity. There are no clues as to why smooth endoplasmic reticulum in Purkinje cells form stacks; stack number can be altered by changes in fixation or damage (see references in Takei et al., 1992).

Cisternal stacks have been previously shown to contain components of the $\mathrm{Ca}^{\text {?+ }}$ rcgulatory system in Purkinje cells (Otsu et al., 1990; Satoh et al., 1990; Villa et al., 1991). Extracellular signals are thought, through the action of second messengers, to induce the release of $\mathrm{Ca}^{2+}$ from intracellular $\mathrm{Ca}^{2+}$-rich compartments (Meldolesi et al., 1990). One constituent of this system is the inositol 1,4,5-triphosphate (IP3) receptor, which is concentrated in the Purkinje cell of the cerebellum, and within these cells is enriched in smooth-surfaced cisternae (Ross, 1989; Otsu et al., 1990; Villa et al., 1991; Walton et al., 1991; Yamamoto et al., 1991; Takei et al., 1992).

The association of neurofibromin with smooth endoplasmic reticulum raises some intriguing questions about the function of neurofibromin. G-proteins, including ras-p21, can regulate certain types of ion channels (Dolphin et al., 1989; Brown and Birnbaumer, 1990; Collin et al., 1990; Yatani et al., 1990). For example, active GTP-bound ras is essential for the release of $\mathrm{Ca}^{3+}$ from intracellular stores in NIH-3T3 cells (Lloyd et al., 1989; Maly et al., 1991). Since neurofibromin can increase the hydrolysis of GTP by ras, we hypothesize that neurofibromin might indirectly modulate intracellular $\mathrm{Ca}^{2+}$ levels within brain neurons from its position in cisternal stacks. It will be of interest to determine if neurofibromin colocalizes with one or more $\mathrm{Ca}^{2+}$ regulatory proteins in the Purkinje cell.

Gutmann and Collins (1992) showed by immunofluorescence that neurofibromin roughly colocalized with microtubules in cultured cell lines. Our results may explain this observation, since endoplasmic reticulum is present in close association with microtubules (Terasaki et al., 1986; Cheng and Reese, 1988; Price et al., 1991). Binding of endocytic vesicles to microtubules is regulated by both ATP and GTP (Scheel and Kreis, 1992). G-proteins in the ras superfamily are distributed in association with organelles throughout the endocytic and exocytic pathways
(Balch, 1990). In addition, molecular motor proteins such as kinesin, dynein, and dynamin are thought to mediate transport of membrane-bounded organelles along microtubules. These proteins localize to intracellular vesicles in immunostaining experiments (Pfister et al., 1989; Scaife and Margolis, 1990). Dynamin is a potent GTPase; kinesin also contains a GTP-binding consensus sequence (Obar et al., 1991; Shpetner and Vallee, 1992). Neurofibromin, by regulating the amount of GTP bound to G-proteins, could provide a link between G-proteins and organelle movement.

\section{References}

Balch WE (1990) Small GTP-binding proteins in vesicular transport. Trends Biochem Sci 15:473-477.

Ballester R, Marchuk D, Boguski M, Saulino A, Letcher R, Wigler M, Collins F (1990) The NFI locus encodes a protein functionally related to mammalian GAP and yeast IRA proteins. Cell 63:851-859.

Bar-Sagi D, Feramisco IR (1985) Microinjection of the ras oncogene protein into PC12 cells induces morphological differentiation. Cell 42:841-848.

Bollag G, McCormick F (1991) Differential regulation of RasGAP and neurofibromatosis gene product activities. Nature 351:576-579.

Borasio GD, John J, Wittinghofer A, Barde Y-A, Sendtner M, Heumann $\mathrm{R}$ (1989) ras $\mathrm{P} 21$ protein promotes survival and fiber outgrowth of cultured embryonic neurons. Neuron 2:1087-1096.

Brown AM, Birnbaumer L (1990) Ionic channels and their regulation by $G$ protein subunits. Annu Rev Physiol 52:197-213.

Buchberg AM, Cleveland LS, Jenkins NA, Copeland NG (1990) Sequence homology shared by neurofibromatosis type- 1 gene and IRA-1 and IRA-2 negative regulators of the RAS cyclic AMP pathway. Nature 347:291-294.

Cawthon RM, Weiss R, Xu G, Viskochil D, Culver M, Stevens J, Robertson M, Dunn D, Gesteland R, O'Connell P, White R (1990) A major segment of the neurofibromatosis type 1 gene: cDNA sequence, genomic structure, and point mutations. Cell 62:193-201.

Cheng TPO, Reese TS (1988) Compartmentalization of anterogradely and retrogradely transported organelles in axons and growth cones from chick optic tectum. J Neurosci 8:3190-3199.

Collin C, Papageorge AG, Lowy DR, Alkon DL (1990) Early enhancement of calcium currents by H-ras oncoproteins injected into Hermissenda neurons. Science 250:1743-1745.

Daston MM, Scrable H, Nordlund M, Sturbaum AK, Nissen LM, Ratner N (1992) The protein product of the neurofibromatosis type 1 gene is expressed at highest abundance in neurons, Schwann cells, and oligodendrocytes. Neuron 8:415-428.

DeClue JE, Cohen BD, Lowy DR (1991) Identification and characterization of the neurofibromatosis type 1 protein product. Proc Natl Acad Sci USA 88:9914-9918.

Dolphin AC, Huston E, Scott RH (1989) Direct and indirect modulation of neuronal calcium currents by G-protein activation. Biochem Soc Symp 56:45-60.

Dufner PK, Cohen ME, Seidel FG, Shucard DW (1989) The significance of MRI abnormalities in children with neurofibromatosis. Neurology 39:373-378.

Dunn DW, Roos KL (1988) Neurofibromatosis: an update. Indiana Med 81:207-215.

Eldridge R, Denckla MB, Bien E, Myers S, Kaiser-Kupfer MI, Pikus A, Schlesinger SL, Parry DM, Dambrosia JM, Zasloff MA, Mulvihill JJ (1989) Neurofibromatosis type 1 (Recklinghausen's disease). Neurologic and cognitive assessment with sibling controls. Am J Dis Child 143:833-837.

Fiori MG, Mugnaini E (1981) Subsurface and cytoplasmic cisterns associated with mitochondria in pyramidal neurons of the rat dorsal cochlear nucleus. Neuroscience 6:461-471.

Fischer TH, Gatling MN, Lacal J-C, White GC (1990) rap1B, a cAMPdependent protein kinase substrate, associates with the platelet cytoskeleton. J Biol Chem 265:19405-19408.

Furth ME, Aldrich TH, Cordon-Cardo C (1987) Expression of ras proto-oncogene proteins in normal human tissues. Oncogene 1:4758.

Guerrero I, Wong H, Pellicer A, Burstein DE (1986) Activated N-ras gene induces neuronal differentiation of $\mathrm{PC} 12$ rat pheochromocytoma cell. J Cell Physiol 129:71-76. 
Gutmann DH, Collins FS (1992) Recent progress toward understanding the molecular biology of Von Recklinghausen neurofibromatosis. Ann Neurol 31:555-561.

Gutmann DH, Wood DL, Collins FS (1991) Identification of the neurofibromatosis type 1 gene product. Proc Natl Acad Sci USA 88: 9658-9662.

Hagag N, Halegoua S, Viola M (1986) Inhibition of growth factorinduced differentiation of $\mathrm{PC} 12$ cells by microinjection of antibody to ras p21. Nature 319:680-682.

Hancock JF, Cadwallader K, Paterson H, Marshall CJ (1991) A CAAX or a CAAL motif and a second signal are sufficient for plasma membrane targeting of ras proteins. EMBO J 10:4033-4039.

Hattori S, Ohmi N, Maekawa M, Hoshino M, Kawakita M, Nakamura S (1991) Antibody against neurofibromatosis type 1 gene product reacts with a Triton-insoluble GTPase activating protein toward ras p21. Biochem Biophys Res Commun 177:83-89.

Herndon RM (1963) The fine structure of the Purkinje cell. J Cell Biol 18:167-180.

Herndon RM (1964) Lamellar bodies, an unusual arrangement of the granular endoplasmic reticulum. J Cell Biol 20:338-342.

Huson SM, Harper PS, Compston DAS (1988) Von Recklinghausen neurofibromatosis. A clinical and population study in South-East Wales. Brain 111:1355-1381.

Kohler G, Milstein C (1976) Derivation of specific antibody-producing tissue culture and tumor lines by cell fusion. Eur J Immunol 6:511519.

Lloyd AC, Davies SA, Crossley I, Whitaker M, Houslay MD, Hall A, Marshall CJ, Wakelam MJO (1989) Bombesin stimulation of inositol 1,4,5-triphosphate generation and intracellular calcium release is amplified in a cell line overexpressing the N-ras proto-oncogene. Biochem J 260:813-819.

Lund AM, Skovby F (1991) Optic gliomas in children with neurofibromatosis type 1. Eur J Pediatr 150:835-838.

Maly K, Kiani A, Oberhuber H, Grunicke H (1991) Interference of Ha-ras with inositol triphosphate-mediated $\mathrm{Ca}^{2+}$-release. FEBS 291: 113-116.

Marchuk DA, Saulino AM, Tavakkol R, Swaroop M, Wallace MR, Andersen LB, Mitchell A, Gutmann DH, Boguski M, Collins FS (1991) cDNA cloning of the type 1 neurofibromatosis gene: complete sequence of the NFI gene product. Genomics 11:931-940.

Marshall M, Hill W, Ng A, Vogel U, Schaber M, Scolnick E, Dixon R, Sigal I, Gibbs J (1989) A C-terminal domain of GAP is sufficient to stimulate ras p21 GTPase activity. EMBO J 8:1105-1110.

Martin GA, Viskochil D, Bollag G, McCabe PC, Crosier WJ, Haubruck $\mathrm{H}$, Conroy L, Clark R, O'Connell P, Cawthon RM, Innis MA, McCormick F (1990) The GAP-related domain of the neurofibromatosis type 1 gene product interacts with ras p21. Cell 63:843-849.

Meldolesi J, Madeddu L, Pozzan T (1990) Intracellular $\mathrm{Ca}^{2+}$ storage organelles in non muscle cells: heterogeneity and functional assignment. Biochim Biophys Acta 1055:130-140.

Morales R, Duncan D (1966) Multilaminated bodies and other unusual configurations of endoplasmic reticulum in the cerebellum of the cat. An electron microscopic study. J Ultrastruct Res 15:480-489.

Moran MF, Polakis P, McCormick F, Pawson T, Ellis C (1991) Protein-tyrosine kinases regulate the phosphorylation, protein interactions, subcellular distribution, and activity of p $21^{\text {ras }}$ GTPase-activating protein. Mol Cell Biol 11:1804-1812.

Mulvihill JJ, Parry DM, Sherman JL, Pikus A, Kaiser-Kupfer MI, Eldridge R (1990) NIH conference: neurofibromatosis 1 (Recklinghausen disease) and neurofibromatosis 2 (bilateral acoustic neurofibromatosis). An update. Ann Intern Med 113:39-52.

Noda M, Ko M, Ogura A, Liu D-G, Amano T, Takano T, Ikawa Y (1985) Sarcoma viruses carrying ras oncogenes induce differentiation-associated properties in a neuronal cell line. Nature 318:73-75.

Obar RA, Shpetner HS, Vallee RB (1991) Dynamin: a microtubuleassociated GTP-binding protein. J Cell Sci 14:143-145.

Otsu H, Yamamoto A, Maeda N, Mikoshiba K, Tashiro Y (1990) Immunogold localization of inositol 1,4,5-triphosphate (InsP $\mathrm{P}_{3}$ ) receptor in mouse cerebellar Purkinje cells using three monoclonal antibodies. Cell Struct Funct 15:163-173.

Pfister KK, Wagner MC, Stenoien DL, Brady ST, Bloom GS (1989) Monoclonal antibodies to kinesin heavy and light chains stain vesiclelike structures, but not microtubules, in cultured cells. J Cell Biol 108: 1453-1463.

Price RL, Lasek RJ, Katz MJ (1991) Microtubules have special phys- ical associations with smooth endoplasmic reticula and mitochondria in axons. Brain Res 540:209-216.

Quinn MT, Mullen ML, Jesaitis AJ, Linner JG (1992) Subcellular distribution of the Rap1A protein in human neutrophils: co-localization and co-translocation with cytochrome b. Blood 79:1563-1573.

Riccardi VM (1981) Von Recklinghausen neurofibromatosis. N Engl J Med 305:1617-1627.

Ridley AJ, Paterson HF, Noble M, Land H (1988) ras-mediated cell cycle arrest is altered by nuclear oncogenes to induce Schwann cell transformation. EMBO J 7:1635-1645.

Rosenbluth J (1962) Subsurface cisterns and their relationship to the neuronal plasma membrane. J Cell Biol 13:405-421.

Ross CA, Meldolesi J, Milner TA, Satoh T, Supattapone S, Snyder SH (1989) Inositol 1,4,5-triphosphate receptor localized to endoplasmic rcticulum in ccrcbellar Purkinje ncurons. Nature 339:468-470.

Satoh T, Ross CA, Villa A, Supattapone S, Pozzan T, Snyder SH, Meldolesi J (1990) The inositol 1,4,5-triphosphate receptor in cerebellar Purkinje cells: quantitative immunogold labeling reveals concentration in an ER subcompartment. J Cell Biol 111:615-624.

Scaife R, Margolis RL (1990) Biochemical and immunochemical analysis of rat brain dynamin interactions with microtubules and organelles in vivo and in vitro. J Cell Biol 111:3023-3033.

Scheel J, Kreis TE (1991) Motor protein independent binding of endocytic carrier vesicles to microtubules in vitro. J Biol Chem 266: 18141-18148.

Shpetner HS, Vallee RB (1992) Dynamin is a GTPase stimulated to high levels of activity by microtubules. Nature 355:733-735.

Takahashi K, Wood RL (1970) Subsurface cisterns in the Purkinje cells of cerebellum of Syrian hamstcr. Z Zcllforsch 110:311-320.

Takei K, Stukenbrok H, Metcalf A, Mignery GA, Südhof TC, Volpe P, De Camilli P (1992) $\mathrm{Ca}^{2+}$ stores in Purkinje neurons: endoplasmic reticulum subcompartments demonstrated by the heterogeneous distribution of the $\mathrm{InsP}_{3}$ receptor, $\mathrm{Ca}^{2+}$-ATPase, and calsequestrin. $\mathrm{J}$ Neurosci 12:489-505.

Tanaka K, Nakafuku M, Satoh T, Marshall M, Gibbs J, Matsumoto K, Kaziro Y, Toh-e A (1990a) $S$. cerevisiae genes $1 R A 1$ and $I R A 2$ encode proteins that may be functionally equivalent to mammalian ras GTPase activating protein. Cell 60:803-807.

Tanaka K, Nakafuku M, Tamanoi F, Kaziro Y, Matsumoto K, Toh-e A (1990b) 1R42, a second gene of Saccharomyces cerevisiae that encodes a protein with a domain homologous to mammalian ras GTPase-activating protein. Mol Cell Biol 10:4303-4313.

Terasaki M, Chen LB, Fujiwara K (1986) Microtubules and the endoplasmic reticulum are highly interdependent structures. J Cell Biol 103:1557-1568.

Villa A, Podini P, Clegg DO, Pozzan T, Meldolesi J (1991) Intracellular $\mathrm{Ca}^{2+}$ stores in chicken Purkinje neurons: differential distribution of the low affinity-high capacity $\mathrm{Ca}^{2+}$ binding protein, calsequestrin, of $\mathrm{Ca}^{2+}$ ATPase and of the ER lumenal protein, Bip. J Cell Biol 113: 779-791.

Viskochil D, Buchberg AM, Xu G, Cawthon RM, Stevens J, Wolff RK, Culver M, Carey JC, Copeland NG, Jenkins NA, White R, O'Connell $P$ (1990) Deletions and a translocation interrupt a cloned gene at the neurofibromatosis type 1 locus. Cell 62:187-192.

Wallace MR, Marchuk DA, Andersen LB, Letcher R, Odeh HM, Saulino AM, Fountain JW, Brereton A, Nicholson J, Mitchell AL, Brownstein BH, Collins FS (1990) Type 1 neurofibromatosis gene: identification of a large transcript disrupted in three NF1 patients. Science 249:181-186.

Walton PD, Airey JA, Sutko JL, Beck CF, Mignery GA, Südhof TC, Deerinck TJ, Ellisman MH (1991) Ryanodine and inositol triphosphate receptors co-exist in avian cerebellar Purkinje neurons. J Cell Biol 113:1145-1157.

Willingham MC, Pastan I, Shih TY, Scolnick EM (1980) Localization of the src gene product of the Harvey strain of MSV to plasma membrane of transformed cells by electron microscopic immunocytochemistry. Cell 19:1005-1014.

Winkelmann A, Kunz G, Winkelmann E, Kirche W, Neumann H, Wenzel J (1973) Quantitative Untersuchungen an Dendriten der grossen Pyramidenzellen der Lamina $\mathrm{v}$ des sensorischen Cortex der Ratte. Himforsch 14:137-149.

Xu G, O'Connell P, Viskochil D, Cawthon R, Robertson M, Culver M, Dunn D, Stevens J, Gesteland R, White R, Weiss R (1990a) The neurofibromatosis type 1 gene encodes a protein related to GAP. Cell 62:599-608. 
Xu G, Lin B, Tanaka K, Dunn D, Wood D, Gesteland R, White R, Weiss R, Tamanoi F (1990b) The catalytic domain of the neurofibromatosis type 1 gene product stimulates ras GTPase and complements ira mutants of $S$. cerevisiae. Cell 63:835-841.

Yamamoto A, Otsu H, Yoshimori T, Maeda N, Mikoshiba K, Tashiro Y (1991) Stacks of flattened smooth endoplasmic reticulum highly enriched in inositol 1,4,5-triphosphate ( $\left(\operatorname{Ins}_{3}\right)$ receptor in mouse cerebellar Purkinje cells. Cell Struct Funct 16:419-432.

Yatani A, Okabe K, Polakis P, Halenbeck R, McCormick F, Brown AM (1990) ras p21 and GAP inhibit coupling of muscarinic receptors to atrial $\mathrm{K}^{+}$channels. Cell 61:769-776. 